\title{
Determination of morpholine residues in apples by liquid chromatography tandem mass spectrophotometry (LC-MS/MS)
}

\author{
Pham Thi Mai Huong1, Vu Thi Trang², Vu Thi Nhat Le ${ }^{2}$, Luu Thi Huyen Trang ${ }^{2 *}$ \\ ${ }^{1}$ Faculty of Chemical Technology, Hanoi University of Industry, Hanoi, Vietnam \\ ${ }^{2}$ National Institute for Food Control, Hanoi, Vietnam
}

(Received: 23/10/2021; Accepted: 23/12/2021)

\begin{abstract}
Morpholine is an emulsifier that is normally used as a protective wax coating on the surfaces of fruit and vegetable. In order to keep fruits fresh, extend their shelf-life, against insect and fungal contamination for a long time, morpholine has been widely applied despite of the reported carcinogenic potential in previous studies and export prohibition in many countries. A highly sensitive method has been developed for the determination of this food additive in fruits using ultra-performance liquid chromatography tandem mass spectrophotometry. By using $1 \%$ acetic acid in methanol for extraction and analyzing with binary ammonium formate $20 \mathrm{mM}$ and acetonitrile, the method has been applied successfully to determine morpholine residues in apple samples collected at local markets in Hanoi, Vietnam. The good coefficient correlation was achieved in the linear range of $5-300 \mu \mathrm{g} / \mathrm{L}\left(\mathrm{R}^{2}=0.9998\right)$. The low limit of detection (LOD) and limit of quantification (LOQ) were 2 and $5 \mu \mathrm{g} / \mathrm{kg}$, respectively. The recoveries of morpholine were $83-108 \%$ over three spike levels $20-60 \mu \mathrm{g} / \mathrm{L}$ for apple, peel and pulp matrices. The repeatability (RSDr \%) was $1.1 \%$ for apple matrix, $2.36 \%$ for peel and $3.67 \%$ for pulp. The reproducibility values (RSDr \%) were 1.49, 3.50 and $4.08 \%$ for apple, peel and pulp, respectively. This method could be further performed in different type of fruit and vegetable comiditities to determine the morpholine content.
\end{abstract}

Keywords: morpholine, UPLC-MS/MS, apple, apple peel, apple pulp.

\section{INTRODUCTION}

Currently, the consumption and export of high-quality fruits are becoming popular, which requires many storage techniques to extend their shelf-life, keep them fresh, good appearance, against insect and fungal contamination before reaching the consumer. To handle this problem, the presence of morpholine, a protective wax coating, is considered as a lifesaving solution for both farmers, consumers during prolonged transit because of its convenience and economy. Morpholine, $\mathrm{C}_{4} \mathrm{H}_{9} \mathrm{NO}$ (fig.1), is a colorless secondary amine ether that has been used as an emulsifier appled thinly on fruits surface, especially in major apple and citrus-producing [1-3]. It is also waxed on the surfaces of fruits to prevent sun damage or insecticide damage during growing up and keep the color of the fruits. However, it is difficult to take this wax coating out of fruits and vegetables if they are washed typically, therefore, it can be absorbed in the body without degradation [4].

Some recent studies show that morpholine can be chemically modified (nitrosated) to form $\mathrm{N}$-nitrosomorpholine (NMOR) with the presence of excess nitrate, which has been proved to be a genotoxic carcinogen in rodents [5]. Thus, it is prohibited for this function under EU food additives legislation EC Regulation 1333/2008 [6]. According to Health Canada, the acceptable intake level for morpholine is $0.48 \mathrm{mg} / \mathrm{kg}$ bw/day based on a chronic oral toxicity study [7].

The accumulation of morpholine has adversely impacted on humans for a long time that has raised an alarming situation about consumer protection health regulation of each country. Therefore, some methods have been developed to monitor and evaluate the level of morpholine residue accurately and regularly such as gas chromatography with flame ionization detection (GC-FID) [8], gas chromatography-tandem mass spectrophotometry (GC-MS) [9], liquid chromatography tandem mass spectrophotometry (LC-MS) [10], 
ultra performance liquid chromatography-high resolution mass spectrophotometry (UPLC-HRMS), etc [11-12]. Mengsi Cao and his colleagues [9] applied the derivatization method by using GC-MS to detect morpholine, however, the derivatization step in treatment was considered difficult to implement. Since, morpholine was added to fruit surfaces at trace level, UPLC-MS/MS method is considered powerful, rapid, selective, sensitive and popular for detection and quantitation of morpholine [9-10]. Different from citrus, apples are fruits that do not need to remove the outer skin when eating, it is possible to absorb a large amount of morpholine when eating apples due to the consumption habit of eating apple peel for the majority. Therefore, this study places special emphasis on apples, apples peel and pulp, and washed apples to recommend the consumption habits of this fruit.

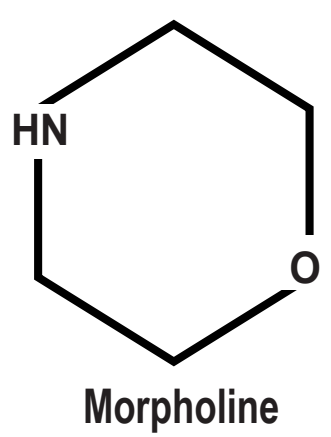

Figure 1. Morpholine structure

\section{MATERIALS AND METHODS}

\subsection{Reagents and materials}

Morpholine standard (99 \% purity) was purchased from Sigma-Aldrich. Other reagents at HPLC analytical grade including acetonitrile, methanol and glacial acetic acid were from Merck. Ultra-pure water was prepared using a Milli-Q water system (Millipore, Billerica, MA, USA).

\subsection{Sample collection}

Apple samples were collected at local markets in Hanoi. They were then separated into four parts including unwashed apple peel, unwashed apple, washed apple, and apple pulp. They were diced and lyophilized and stored at $-80^{\circ} \mathrm{C}$ until analysis within one month. The freeze samples were ground with a blender before analysis.

\subsection{Sample preparation}

Approximately 5 - $7 \mathrm{~g}$ of homogenized sample was weighted into a $50 \mathrm{~mL}$ polypropylene centrifuge tube. Add $1-2 \mathrm{~mL}$ of water and followed by $10 \mathrm{~mL}$ of extract solvent to the tube. The investigated extract solvents were: the mixture of $1 \%$ acetic acid in methanol, acetonitrile/water $(1: 1)$, and $1 \%$ formic acid in methanol. Shake horizontally by a mechanical shaker for 15 minutes (ultrasound without temperature if necessary) and centrifuged at 6,000 rpm for five minutes. The aliquot of the extract was transferred into a $25 \mathrm{~mL}$ volumetric flask. Reduplicate the previous extraction with $10 \mathrm{~mL}$ of extract solvent. Combine the aliquot, dilute to $25 \mathrm{~mL}$. The extract was filtered through a $0.2 \mu \mathrm{m}$ PTFE syringe filter before being analyzed by UPLC-MS/MS.

\subsection{UPLC-MS/MS condition}

The analysis process was operated by using Waters Acquity UPLC system (binary) coupled to a Waters Xevo TQD mass spectrometer via electrospray ionization (ESI). The chromatography separation was conducted with HILIC column $(100 \mathrm{~mm} \times 2.1 \mathrm{~mm} \times 5 \mu \mathrm{m})$ at the column temperature of $40^{\circ} \mathrm{C}$. The mobile phase was ammonium formate $20 \mathrm{mM}$ (A) and acetonitrile (B). The constant flow rate was $0.5 \mathrm{~mL} / \mathrm{min}$ with the ratio of A:B was $60: 40(\mathrm{v} / \mathrm{v})$. The injection volume was $10 \mu \mathrm{L}$. The total run time was ten minutes.

The precursor was 87.8 and two different ions (41.8 and 69.9) were selected to detect and quantify morpholine at the selected reaction monitoring (SRM) mode. The cone (V) was 25 and collision energy (V) was 16 for the primary transition $(87.8>41.8)$, and for the secondary transition $(87.8>69.9)$ they were 25 and 16 , respectively. 


\subsection{Method validation}

This method was validated for linearity, LOD, LOQ, repeatability, reproducibility, recovery, and measurement uncertainty. The calibration curve was conducted using working standard solutions at the concentrations of 5, 10, 25, 50, 100, 200, $300 \mu \mathrm{g} / \mathrm{L}$. LOD and LOQ were calculated as LOD (limit of detection) $=3.3 \times \mathrm{S} / \mathrm{N}$ and LOQ (limit of quantitiation) $=10 \times \mathrm{S} / \mathrm{N}$, where $\mathrm{S} / \mathrm{N}$ is the signal/noise ratio.

To evaluate the precision (intra-day repeatability RSDr \% and inter-day reproducibility RSDR \%), the experiment was repeated six times $(n=6)$ with the same sample, equipment and operator in a day. For reproducibility, $\mathrm{n}=10$ for two operators on different days. The recoveries were performed with three known amounts of morpholine $(20,35$, and $60 \mu \mathrm{g} / \mathrm{L})$, which were added to the matrices with three replicates at each level. The measurement uncertainty was also estimated for the morpholine analysis method in apple using the combined standard uncertainty. To obtain measurement uncertainty (U), a coverage factor of $\sim 95 \%$, where $\mathrm{k}=2$, was used.

\subsection{Morpholine analysis in real samples}

After sample collection, morpholine was determined in four different matrices: unwashed apple peel, apple pulp, unwashed apple, and washed apple using the proposed method. After that, sample solutions are analyzed in UPLC-MS/MS. Based on the calibration curves, the concentration of each sample can be measured. Evaluate and compare the content of morpholine in different apple matrices.

\section{RESULTS AND DISCUSSIONS}

\subsection{Optimization of mobile phase composition}

Effects of different mobile phases on the target compound signal and retention were investigated. The experiments were designed in the combination of acetonitrile and water with/without a variety of modifiers including water and acetonitrile; $20 \mathrm{mM}$ ammonium formate and acetonitrile; $0.1 \%$ formic acid and acetonitrile. The $20 \mathrm{mM}$ ammonium formate solution was selected as the most suitable mobile phase because of the higher sensitivity and better peak symmetry than using water and acetonitrile.

\subsection{The extraction procedure optimization}

The morpholine extraction was performed with $1 \%$ acidic methanol and a small amount of water $(1-2 \mathrm{~mL})$ [9]. Thus, the extraction efficiency was studied for the mixture of $1 \%$ acetic acid in methanol, acetonitrile/water $(1: 1)$, and $1 \%$ formic acid in methanol. It can be seen in Figure 2, the extraction efficiency for morpholine was better at $1 \%$ acetic acid in methanol than that at acetonitrile/water $(1: 1$, $\mathrm{v} / \mathrm{v}$ ) and $1 \%$ formic acid in methanol, based on the recoveries of morpholine. As a result, $1 \%$ acetic acid in methanol is chosen for sample treatment in this study.

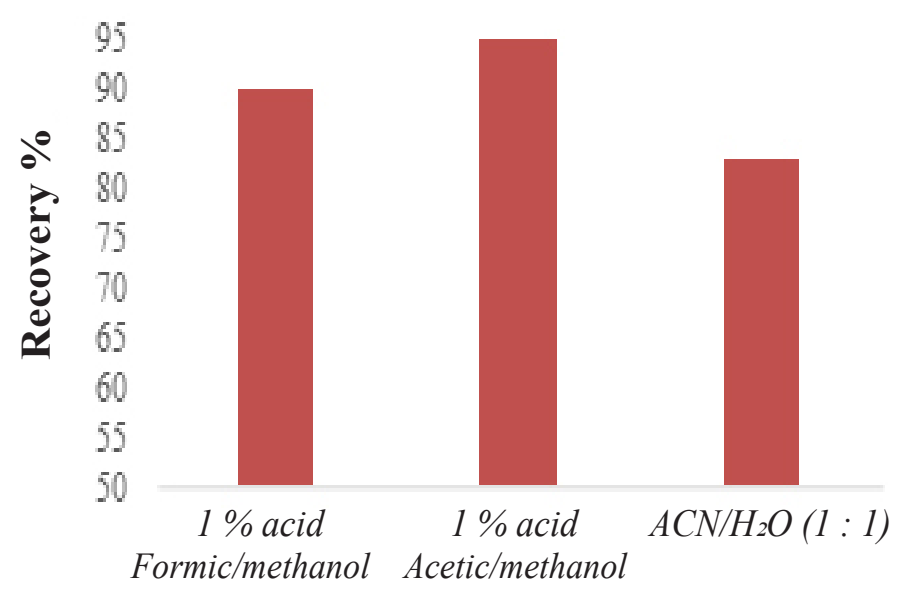

Extraction solvent

Figure 2. Recoveries of morpholine in different extraction solvents 


\subsection{Method validation}

The quantification of morpholine using the UPLC-MS/MS method was validated with the following criteria: linear range, calibration curve, precisions (RSDr \%, RSDR \%), and accuracy (recovery \%).

Linear range and calibration curve: The results are shown in Figure 3 . The correlation coefficient $\left(\mathrm{R}^{2}\right)$ of the calibration curve showed high linearity over a linear range of $5-300 \mu \mathrm{g} / \mathrm{L}$.

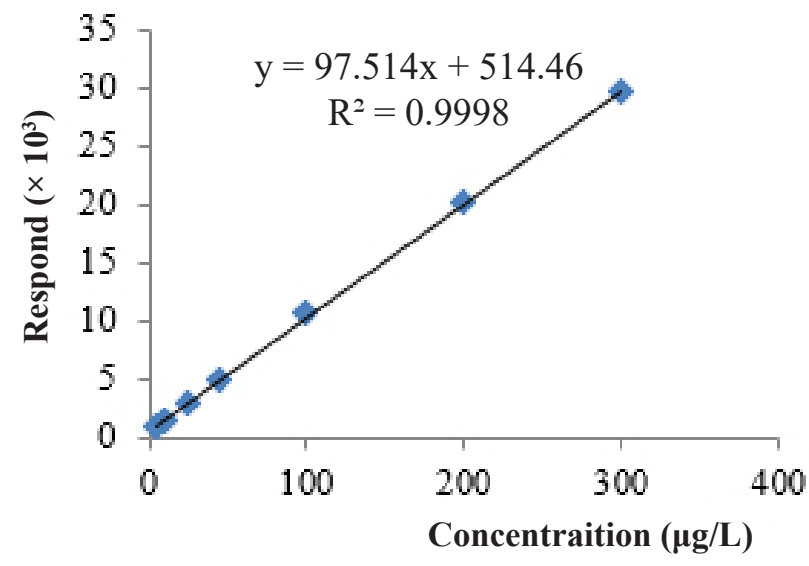

Figure 3. Calibration curve of morpholine

The chromatograms of $100 \mu \mathrm{g} / \mathrm{L}$ morpholine standard from Water Xevo TQD with MRM transition $87.8>69.9$ and $87.8>41.8$ were presented in Figure 4.

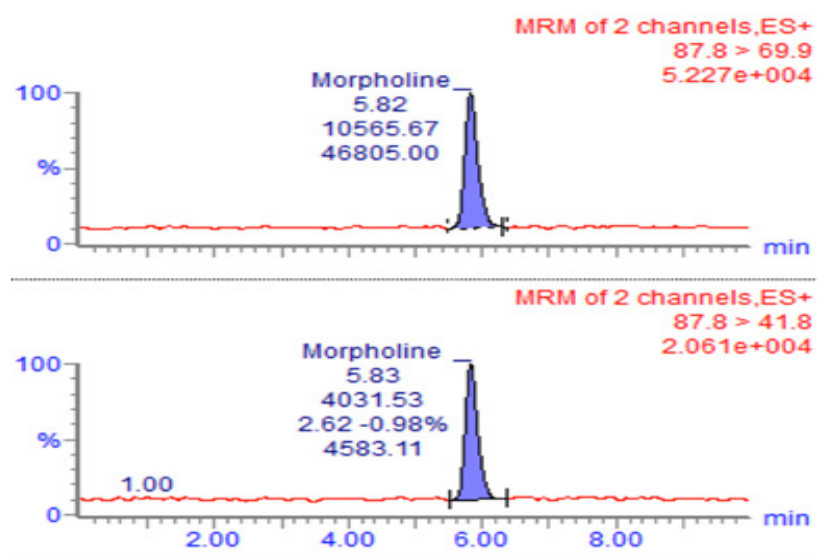

Figure 4. Chromatography of $100 \mu \mathrm{g} / \mathrm{L}$ morpholine standard (69.9 ion for quantitation and 41.8 ion for qualification)

The limit of detection (LOD) and limit of quantification (LOQ) values were 2 and $5 \mu \mathrm{g} / \mathrm{kg}$, respectively by calculating as 3.3 and 10 times the signal/noise $(\mathrm{S} / \mathrm{N})$ ratio.

Repeatability, Reproducibility, and Recovery were presented in Table 1. All the results satisfy the requirements of $\mathrm{AOAC}$ [13].

The measurement uncertainty of morpholine was estimated from the recovery values according to the Nordtest approach. The expanded uncertainties Uc for apple, apple peel, and apple pulp were 15.6, 10.3, and $11.2 \%$, respectively, with $\mathrm{k}=2$.

Table 1. Repeatability, Reproducibility and Recovery of morpholine in apple matrices

\begin{tabular}{cccc}
\hline Matrix & RSDr \% & RSD $\%$ & Recovery \% \\
\hline Apple & 1.10 & 1.49 & $87-108$ \\
\cline { 2 - 4 } Peel & 2.36 & 3.50 & $85-106$ \\
\cline { 2 - 4 } Pulp & 3.67 & 4.08 & $83-108$ \\
\hline
\end{tabular}


The obtained results proved that the analytical method is suitable for the determination of morpholine at low concentration.

\subsection{Determination of morpholine content in real samples}

The developed method was used to determine the morpholine residues in four matrices: unwashed apple peel, unwashed apple, and washed apples and apple pulp from the local markets in Hanoi. The analysis data was shown in Table 2. The levels of morpholine in the washed apple and the unwashed apple are quite clearly different. Morpholine was not found in the pulp but was significantly detected in the peel.

Table 2. Average morpholine concentration in four apple matrices

\begin{tabular}{|c|c|c|c|}
\hline \multicolumn{4}{|c|}{ Average morpholine content $(\mu \mathrm{g} / \mathrm{kg})$} \\
\hline & Apple 1 & Apple 2 & Apple 3 \\
\hline Apple peel & $1887 \pm 194$ & $673 \pm 69$ & $N D$ \\
\hline Unwashed apple & $969 \pm 151$ & $234 \pm 37$ & $N D$ \\
\hline Washed apple & $612 \pm 95$ & $96 \pm 15$ & $N D$ \\
\hline Apple pulp & $N D^{*}$ & $N D$ & $N D$ \\
\hline
\end{tabular}

From the results of Table 2, it was indicated that not all apples in the markets have applied morpholine onto the surfaces of apples for preservation. Some species were found in a high concentration of morpholine, others were not detected in the presence of it. This advises consumers in choosing products with a reputation for product quality.

Figure 5 was shown that no detection of any morpholine ion at the same time in apple pulp matrix compared with chromatogram of apple peel matrix. Thus, the apple should be washed and peeled before consumption to prevent the exposure of morpholine residue in apple peel.

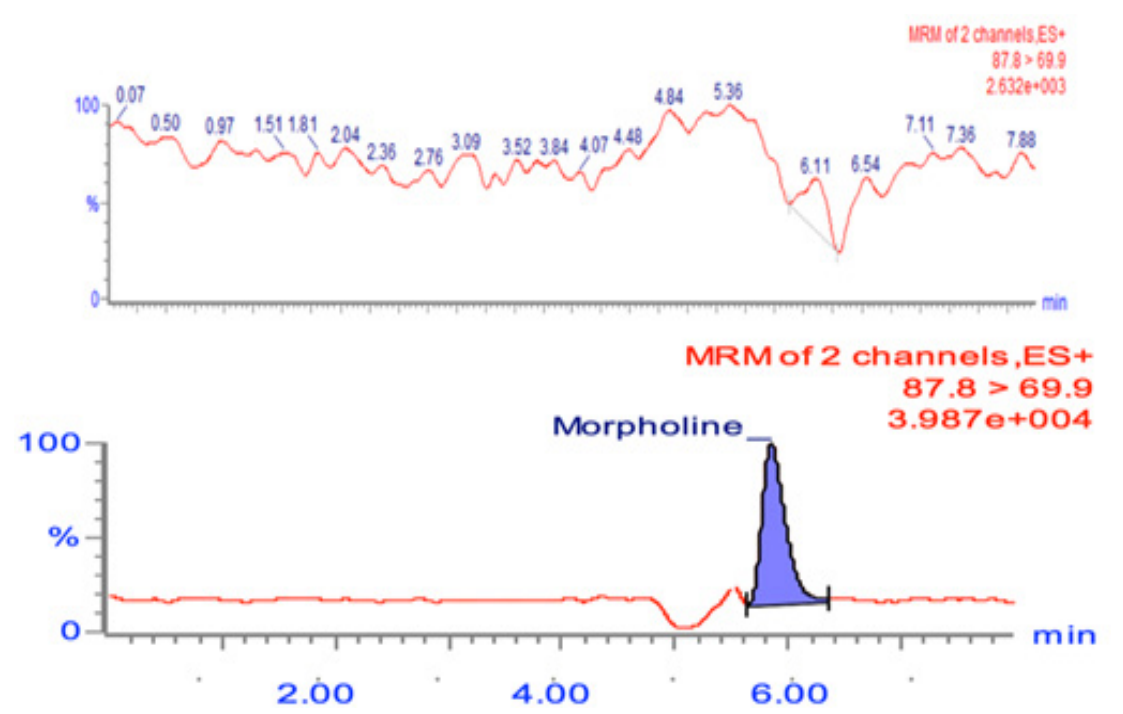

Figure 5. Chromatograms of morpholine in apple peel (below) and apple pulp (above)

\section{CONCLUSIONS}

UPLC-MS/MS is proved to be useful technique to detect and quantify a small amount of morpholine in fruit commodities with high precision and accuracy in a broad linear range. The LOD and LOQ were low enough to quantify morpholine residues in apple matrices. Morpholine was found in some apple samples purchased at local markets in Hanoi by this mentioned method. This phenomenon raises the concern about the use of morpholine in the preservation of fruits and vegetables. Thus, this method should be used to monitor the morpholine residues in larger numbers of samples for further study. 


\section{REFERENCES}

[1]. K. An, I. Kim, C. Lee, J. Moon, H. Suh, and J. Lee, "Quantification of Morpholine in Peel and Pulp of Apples and Oranges by Gas Chromatography - Mass Spectrometry," Foods, vol. 9, no. 6, pp.746, 2020.

[2]. P. Cao, D. Chen, J. Liang, P. Wu, S. Wen, J. Wei, S. Liu, X. Wu, Y. Zhao, and H. Xu, "Concentration of morpholine residues in major fruits and juices and its dietary exposure in China," Food Additives \& Contaminants: Part A, vol. 36, no. 1, pp.26-34, 2019.

[3]. M. J. Walker, K. Gray, C. Hopley, D. Bell, P. Colwell, P. Maynard, and D.T. Burns, "Forensically Robust Detection of the Presence of Morpholine in Apples - Proof of Principle," Food Analytical Methods, vol. 5, no. 4, pp. 874-880, 2011.

[4]. E. Kuchowicz and K. Rydzyn Ãåski, "Risk assessment of morpholine (tetrahydro-2H-1, 4-oxazine): A time for reevaluation of current occupational exposure standards?, Applied Occupational and Environmental Hygiene, vol. 13, no. 2, pp.113-121, 1998.

[5]. R. Kumar and S. Kapur, "Morpholine: A Glazing Agent for Fruits and Vegeatables Coating/Waxing, ” International Journal of Science Technology \& Engineering, vol. 2, no. 11, pp. 694-697, 2016

[6]. European Commission. Food Additives. "Database”. [Online]. Available: https://ec.europa.eu/food/ /food-improvement-agents/additives/database_en. [Accessed Sept 2021].

[7]. Health Canada. "Archived-A Summary of health hazard assessment of morpholine in wax coatings of apples,". [Online]. Available: https:/www.canada.ca/en/health-canada/services/food-nutrition/ food-safety/information-product/summary-health-hazard-assessment-morpholine-coatings-apples. html. [ Accessed 23/10/2021].

[8]. J. Luong, R. A. Shellie, H. Cortes, R. Gras, and T. Hayward, "Ultra-trace level analysis of morpholine, cyclohexylamine, and diethyl aminoethanol in steam condensate by gas chromatography with multi-mode inlet, and flame ionization detection," Journal of Chromatography A, vol. 1229, pp. 223-229, 2012.

[9]. JM. Cao, P. Zhang, Y. Feng, H. Zhang, H. Zhu, K. Lian, and W. Kang, "Development of a method for for rapid determination of morpholine in juices and drugs by gas chromatography-mass spectrometry," Journal of Analytical Methods in Chemistry, vol 2018, pp.1-8, 2018.

[10]. L. Sabatino, M. Scordino, R. Caruso, E. Chiappara, P. Traulo, A. Belligno, and G. Gagliano, "LC/MS/MS detection of short-chain aliphatic amines in glazing agents for fruit coating," European Food Research and Technology, vol. 235, no. 1, pp. 177-184., 2012.

[11]. M. Hengel, R. Jordan, and W. Maguire, "Development and validation of a standardized method for the determination of morpholine residues in fruit commodities by liquid chromatography-mass spectrometry," Journal of Agricultural and Food Chemistry, vol. 62, no. 17, pp. 3697-3701, 2018.

[12]. Chen. D, Miao. H, Zou. J, Cao. P, Ma. N, Zhao. Y, Wu. Y, "Novel Dispersive Micro-Solid-Phase Extraction Combined with Ultrahigh-Performance Liquid Chromatography-High-Resolution Mass Spectrometry To Determine Morpholine Residues in Citrus and Apples," Journal of Agricultural and Food Chemistry, vol. 63, no. 2, pp. 485-492, 2015.

[13]. AOAC Official Methods of Analysis, Guidelines for Standard Method Performance Requirements, Appendix F, 2016. 


\title{
Xác định hàm lượng morpholine trong táo bằng phương pháp sắc ký lỏng hiệu năng cao kết hợp với detector khối phổ hai lần
}

\author{
Phạm Thị Mai Hương', Vũ Thị Trang², Vũ Thị Nhật Lệ, Lưu Thị Huyền Trang² \\ ${ }^{1}$ Khoa Công nghệ Hóa, Trương Đại học Công nghiệp Hà Nội, Hà Nội, Việt Nam \\ ${ }^{2}$ Viện Kiểm nghiệm an toàn vệ sinh thưc phẩm Quốc gia, Hà Nội, Việt Nam
}

\section{Tóm tắt}

Morpholine là một chất nhũ hóa thường được sử dụng như một lớp sáp phủ trên bề mặt của các loại trái cây và rau quả. Với mục đích giữ cho trái cây tươi lâu, kéo dài thời hạn sử dụng, ngăn ngừa sự xâm nhập của côn trùng và nấm mốc trong thời gian dài, morpholine đã được sử dụng rộng rãi mặc dù chất này đã được báo cáo về khả năng gây ung thư trong các nghiên cứu trước đây và bị cấm xuất khẩu ở nhiều nước. Phương pháp sắc ký lỏng siêu hiệu năng kết hợp với detector khối phổ hai lần được đánh giá là phương pháp có độ nhạy cao, phù hợp để xác định dư lượng morpholine trong trái cây. Bằng việc sử dụng dung môi chiết acid acetic $1 \%$ trong methanol và chương trình phân tích đẳng dòng với thành phần pha động amoni format $20 \mathrm{mM}$ và acetronitrile, phương pháp này được áp dụng thành công để xác định dư lượng morpholine trong các mẫu táo được thu thập tại một số chợ ở Hà Nội. Hệ số tương quan đạt được tốt trong khoảng tuyến tính từ $5-300 \mu \mathrm{g} / \mathrm{L}\left(\mathrm{R}^{2}=0,9998\right)$. Giới hạn phát hiện và giới hạn định lượng của phương pháp thấp, lần lượt là 2 và $5 \mu \mathrm{g} / \mathrm{kg}$. Độ thu hồi của morpholine là $83-108 \%$ trên ba mức thêm chuẩn $20-60 \mu \mathrm{g} / \mathrm{L}$ đối với nền táo, vỏ và thịt táo. Độ lặp lại (RSDr \%) là 1,1 \% trên nền táo, 2,36 \% đối với vỏ và 3,67 \% đối với thịt táo. Các giá trị độ tái lập (RSDR \%) tương ứng là $1,49,3,50$ và 4,08 \% đối với táo, vỏ và thịt táo. Phương pháp này có thể được áp dụng để phân tích dư lượng morpholine trong các mặt hàng rau củ quả khác nhau trên thị trường.

Tù khóa: Morpholine, UPLC-MS/MS, táo, vỏ táo, thịt táo. 